Article

\title{
Atmospheric Nitrogen Deposition to a Southeast Tibetan Forest Ecosystem
}

\author{
Wei Wang ${ }^{1, *}$, Lixue Guan ${ }^{1}$, Zhang Wen ${ }^{2}$, Xin Ma ${ }^{2}$, Jiangping Fang ${ }^{1}$ and Xuejun Liu ${ }^{2}$ (I) \\ 1 Key Laboratory of Forest Ecology in Tibet, Ministry of Education, Tibet Agriculture \& Animal \\ Husbandry University, Nyingchi, Tibet 860000, China; B133166199@163.com (L.G.); xzfjp@sina.com (J.F.) \\ 2 Key Laboratory of Plant-Soil Interactions of MOE, College of Resources and Environmental Sciences, \\ National Academy of Agriculture Green Development, China Agricultural University, Beijing 100193, China; \\ wenzhang0830@163.com (Z.W.); 13503608816@163.com (X.M.); Liu310@cau.edu.cn (X.L.) \\ * Correspondence: xzwangwei@xza.edu.cn
}

Received: 1 November 2020; Accepted: 5 December 2020; Published: 8 December 2020

check for updates

\begin{abstract}
With atmospheric reactive nitrogen ( $\mathrm{Nr}$ ) emissions increasing globally, research into $\mathrm{Nr}$ deposition has attracted increasing attention, especially in remote environments. These ecosystems are very sensitive to global change, especially enhanced $\mathrm{Nr}$ deposition. Forest environments, in particular, are highlighted because of their important ecological function. We quantified atmospheric $\mathrm{Nr}$ concentrations and deposition over four years of continuous monitoring in a southeast Tibetan boreal forest ecosystem, an ecosystem in which forest biomass and carbon density are high around the world. Average annual bulk $\mathrm{Nr}$ deposition was $3.00 \mathrm{~kg} \mathrm{~N} \mathrm{ha}^{-1} \mathrm{y}^{-1}$, with those of reduced and oxidized species estimated at 1.60 and $1.40 \mathrm{~kg} \mathrm{~N} \mathrm{ha}^{-1} \mathrm{y}^{-1}$, respectively. Bulk deposition of both $\mathrm{NH}_{4}{ }^{+}$and $\mathrm{NO}_{3}{ }^{-}$were controlled by precipitation amount: both $\mathrm{Nr}$ deposition and precipitation were highest in summer and lowest in winter. Dry deposition of $\mathrm{NH}_{3}$ and $\mathrm{NO}_{2}$ were 1.18 and $0.05 \mathrm{~kg} \mathrm{~N} \mathrm{ha}^{-1} \mathrm{y}^{-1}$, respectively. Atmospheric $\mathrm{NH}_{3}$ concentrations were in the range $1.15-3.53 \mathrm{mg} \mathrm{N} \mathrm{L}^{-1}$, highest in summer and lowest in winter. In contrast, no clear trend in seasonal $\mathrm{NO}_{2}$ concentrations was observed. Monthly $\mathrm{NO}_{2}$ concentrations were $0.79-1.13 \mathrm{mg} \mathrm{N} \mathrm{L}^{-1}$. Total $\mathrm{Nr}$ deposition (bulk plus dry) was 4.23 $(3.00+1.23) \mathrm{kg} \mathrm{N} \mathrm{ha}^{-1} \mathrm{y}^{-1}$ in the forest. Reduced nitrogen was the dominant species. In conclusion, $\mathrm{Nr}$ deposition was in the range at which forest net productivity and carbon sequestration are sensitive to any variation in nitrogen input, so quantification of $\mathrm{Nr}$ deposition should continue and with greater detail.
\end{abstract}

Keywords: Southeast Tibet; forest ecosystem; nitrogen deposition; reduced nitrogen; oxidized nitrogen

\section{Introduction}

With rapid economic growth (e.g., agricultural, industrial, urbanization), atmospheric reactive nitrogen (Nr) deposition has increased significantly and has caused a series of ecological and environmental problems [1,2], especially in China [3] and many developing countries in recent years [4]. In order to evaluate the potential effects caused by additional nitrogen inputs via atmospheric deposition, $\mathrm{Nr}$ deposition has been measured in different environments around the world [5-7], including forest ecosystems [8-10].

$\mathrm{Nr}$ deposition to forests can result in both harmful and beneficial effects. Generally, additional $\mathrm{Nr}$ inputs to already N-rich ecosystems result in soil acidification, nutrient imbalance and a decrease in plant diversity $[11,12]$. However, positive effects, such as additional carbon sequestration, can be caused by enhanced $\mathrm{N}$ deposition in N-limited environments [13]. In China, tropical and subtropical forests are $\mathrm{N}$-rich ecosystems, but temperate and boreal forests are $\mathrm{N}$-limited [14]. Due to the high 
population density and intensive human activity in tropical and subtropical regions, $\mathrm{Nr}$ deposition is relatively high in these areas [15]. Therefore, the impacts of increasing $\mathrm{Nr}$ deposition and its impacts have been quantified in south China, where these forests are found [16,17]. In contrast, quantification of fluxes and impacts of $\mathrm{Nr}$ are rare in boreal forests because $\mathrm{Nr}$ deposition and human disturbance have been traditionally considered as low. However, $\mathrm{Nr}$ pollution has no bounds [18]. It has been reported that tree growth rates have accelerated in boreal forests, even where human activity is limited [19], and carbon sequestration was significantly enhanced in forests when $\mathrm{Nr}$ deposition was between 3 and $11 \mathrm{~kg} \mathrm{~N} \mathrm{ha}^{-1} \mathrm{yr}^{-1}$ [20]. In conclusion, although no substantial deleterious effects of $\mathrm{Nr}$ pollution have been observed in low $\mathrm{N}$ deposition regions, quantification of $\mathrm{Nr}$ deposition fluxes in boreal forest ecosystems is crucial because both net productivity and carbon sequestration are sensitive to additional nitrogen inputs.

The Qinghai-Tibet Plateau is considered to be an N-limited ecosystem, sensitive to global change, such as increased $\mathrm{Nr}$ deposition [21,22]. To date, quantification of $\mathrm{Nr}$ deposition using long-term in situ monitoring is rare in this region because of limited access and technical resources. Sporadic research has revealed that $\mathrm{Nr}$ deposition is relatively low but has increased in Nyingchi City, the main city in the region, during recent years [23]. In fact, large spatial variation in $\mathrm{Nr}$ deposition exists in the plateau, as high as $18 \mathrm{~kg} \mathrm{~N} \mathrm{ha}^{-1} \mathrm{y}^{-1}$ in urban areas and as low as $0.44 \mathrm{~kg} \mathrm{~N} \mathrm{ha}^{-1} \mathrm{y}^{-1}$ in remote areas [24,25], but none of the previous research has focused on forest ecosystems in the plateau. Understanding $\mathrm{Nr}$ deposition is essential, especially in the southeast Tibetan boreal forest ecosystem, which has one of the highest levels of carbon storage and carbon density in forest ecosystems around the world [26]. We, therefore, established an in situ monitoring site and continuously measured $\mathrm{Nr}$ deposition for four years in a boreal forest ecosystem at Sejila Mountain in the Qinghai-Tibet Plateau, with the aim of: (1) measuring current atmospheric $\mathrm{Nr}$ concentrations and $\mathrm{Nr}$ deposition to the forest; (2) quantifying the dominant $\mathrm{Nr}$ deposition species. The results will help us to predict the positive or negative effects that would occur in a southeast Tibetan boreal forest ecosystem from enhanced $\mathrm{Nr}$ deposition.

\section{Experiments}

\subsection{Sampling Location}

The Nr deposition monitoring site was established at the National Field Scientific Observation Station of Alpine Forest Ecosystem ( $29^{\circ} 38^{\prime} \mathrm{N}, 94^{\circ} 42^{\prime} \mathrm{E}, 3950 \mathrm{~m}$ a.s.l.) (Figure 1). This is part of the Chinese Forest Ecosystem Research Network (CFERN) and National Ecosystem Research Network of China (CEORN). The annual average precipitation and average temperature were approximately $1000 \mathrm{~mm}$ and $-0.73{ }^{\circ} \mathrm{C}$, respectively. The station is surrounded by local primary fir forest, and there is no $\mathrm{Nr}$ pollution source nearby, except for one state road (\#318). The dominant vegetation species is Abies georgei var. Smithii. Most of these trees are more than one hundred years old. The undergrowth is Sorbus (Sorbus rehderiana var. rehderiana), Rosa (Rosa omeiensis, Rosa sikangensis), and Lonicera (Lonicera saccata; Lonicera angustifolia) as well as other herbaceous plants.

\subsection{Precipitation and Gaseous Nr Measurements}

Precipitation was collected with simple precipitation gauges from January 2016 to December 2019. This method has been widely used in previous studies [27]. Briefly, a gauge (SDM6, Tianjin Weather Equipment Inc., Tianjin, China) was placed on the roof at the observation station where there were no surrounding obstacles. The gauge was continuously open, and precipitation (rainwater and snow) collected by hand once a week. (The samples will therefore contain wet and some dry deposition). Collected samples were transferred to $50 \mathrm{~mL}$ pre-cleaned plastic bottles and stored at $-18{ }^{\circ} \mathrm{C}$ until analyzed. After each sampling, deionized water was used to wash the steel funnel and glass bottles of the rain gauge to eliminate contamination. 


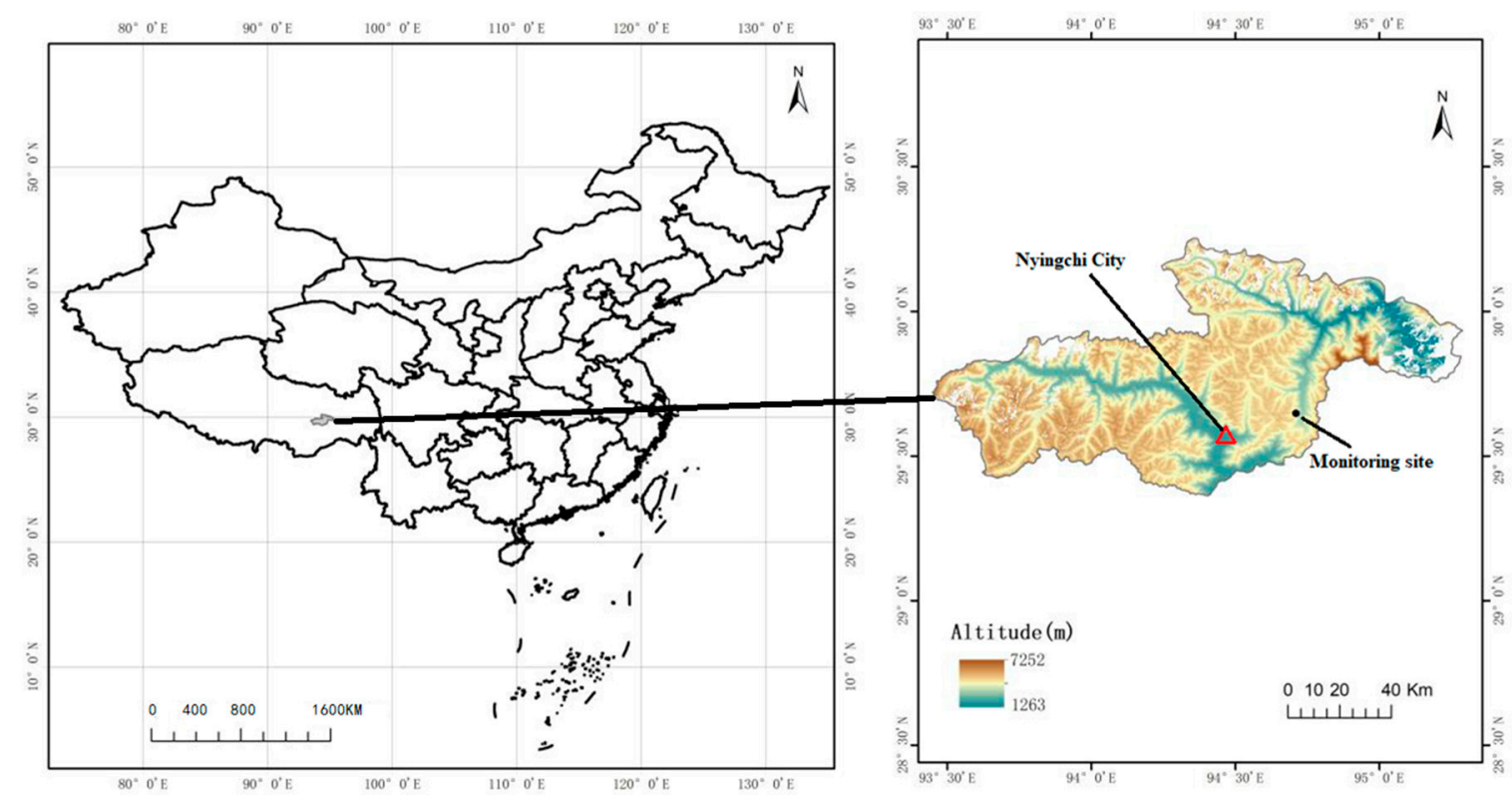

Figure 1. Location of the Nyingchi City and nitrogen deposition monitoring site.

Atmospheric $\mathrm{NH}_{3}$ and $\mathrm{NO}_{2}$ only were measured using passive samplers. This is commonly accepted as providing an approximate measure of atmospheric $\mathrm{Nr}$ concentrations [28]. $\mathrm{NH}_{3}$ was captured using adapted low-cost, high absorption (ALPHA; designed by the Center for Ecology and Hydrology, Edinburgh, UK) passive samplers; $\mathrm{NO}_{2}$ was collected using Gradko diffusion tubes (Gradko International Limited, Winchester, UK). ALPHA passive samplers and Gradko diffusion tubes were fixed beside the rain gauge at the height of $2 \mathrm{~m}$ above the roof and exchanged with new samplers or diffusion tubes on the first day of each month. There were three duplicate ALPHA samplers and diffusion tubes. Both $\mathrm{NH}_{3}$ and $\mathrm{NO}_{2}$ samples were measured within $48 \mathrm{~h}$ of sampling.

\subsection{Analytical Procedures}

Precipitation samples were analyzed as in a previous study [28]. Briefly, samples were thawed and filtered through a syringe filter $\left(0.45 \mu \mathrm{m}\right.$, Tengda Inc., Tianjin, China). $\mathrm{NH}_{4}{ }^{+}$and $\mathrm{NO}_{3}{ }^{-}$in the filtered solutions were measured by AA3 continuous-flow analysis (Bran + Luebbe GmbH, Norderstedt, Germany). The detection limits were $0.01 \mathrm{mg} \mathrm{N} \mathrm{L}^{-1}$.

Gaseous $\mathrm{NH}_{3}$ captured by ALPHA samplers was extracted with $10 \mathrm{~mL}$-high-purity water and measured by AA3 continuous-flow analyzer as above. Gaseous $\mathrm{NO}_{2}$ captured by Gradko diffusion tubes was extracted with a solution containing sulfanilamide, $\mathrm{H}_{3} \mathrm{PO}_{4}$ and $\mathrm{N}-1$-Naphthylethylen-diamine, and the concentration of $\mathrm{NO}_{2}{ }^{-}$determined by colorimetry at a wavelength of $542 \mathrm{~nm}$. A blank sample was measured at the same time to eliminate errors.

\subsection{Calculations and Statistical Analysis}

Bulk Nr deposition $\left(\mathrm{N}_{\mathrm{b}}\right)$ was calculated as the $\mathrm{Nr}$ concentration $\left(\mathrm{N}_{\mathrm{c}}\right)$ multiplied by precipitation amount $(\mathrm{P})$ in each precipitation event using:

$$
\mathrm{N}_{\mathrm{b}}=\mathrm{N}_{\mathrm{c}} \times \mathrm{P} \times 10^{-2}
$$

$\mathrm{NH}_{4}{ }^{+}$and $\mathrm{NO}_{3}{ }^{-}$were calculated independently. The units of $\mathrm{N}_{\mathrm{b}}, \mathrm{Nc}$ and $\mathrm{P}$ were $\mathrm{kg} \mathrm{N} \mathrm{ha}^{-1}$, $\mathrm{mg} \mathrm{N} \mathrm{L}{ }^{-1}$ and $\mathrm{mm}$, respectively. $10^{-2}$ is a unit conversion factor. 
Monthly bulk $\mathrm{Nr}$ deposition $\left(\mathrm{N}_{\mathrm{s}}\right)$ was calculated by summing all bulk deposition fluxes collected in a month, as follows:

$$
\mathrm{N}_{\mathrm{s}}=\sum_{0}^{i} \mathrm{~N}_{\mathrm{b}}
$$

where $i$ represents the number of samples in the month.

The monthly $\mathrm{Nr}$ concentration $\left(\mathrm{N}_{\mathrm{c}}\right)$ in precipitation was calculated by dividing $\mathrm{N}_{\mathrm{s}}$ by precipitation amount $\left(\mathrm{P}_{\mathrm{s}}\right)$ in the month:

$$
\begin{aligned}
& \mathrm{N}_{\mathrm{c}}=\mathrm{N}_{\mathrm{s}} / \mathrm{P}_{\mathrm{s}} \\
& \mathrm{P}_{\mathrm{s}}=\sum_{0}^{i} \mathrm{P}
\end{aligned}
$$

where $i$ represents the number of precipitation events in the month.

Dry deposition was calculated as the atmospheric $\mathrm{Nr}$ concentration multiplied by the deposition velocity. Monthly atmospheric $\mathrm{Nr}$ concentrations were obtained from the measured $\mathrm{NH}_{3}$ and $\mathrm{NO}_{2}$ concentrations and deposition velocities in forests from Flechard et al. [10]; these have been widely used to estimate $\mathrm{Nr}$ deposition in forest environments [29,30]. Deposition velocities of $\mathrm{NH}_{3}$ and $\mathrm{NO}_{2}$ were $1.6 \mathrm{~cm} \mathrm{~s}^{-1}$ and $0.16 \mathrm{~cm} \mathrm{~s}^{-1}$, respectively.

We defined March to May as spring, June to August as summer, September to November as autumn, and December, January and February as winter.

Variance analysis was performed by SPSS 19.0. The Duncan test was used to test the significance between monthly precipitation amounts, $\mathrm{NH}_{4}{ }^{+}$deposition, $\mathrm{NO}_{3}{ }^{-}$deposition, and atmospheric $\mathrm{NH}_{3}$ and $\mathrm{NO}_{2}$ concentrations. Figures were drawn with originPro8.

\section{Results}

\subsection{Variation in Monthly Precipitation and $\mathrm{NO}_{3}{ }^{-}$and $\mathrm{NH}_{4}{ }^{+}$Deposition}

Precipitation varied throughout the year (Figure 2a), first increasing and then decreasing. It was highest in July $(183.4 \mathrm{~mm})$ and lowest in December $(3.35 \mathrm{~mm})$. No significant differences between amounts of precipitation in July and August were observed, based on the Duncan test. Precipitation in January, February, November and December were also similar. Variation in both $\mathrm{NO}_{3}{ }^{-}-\mathrm{N}$ and $\mathrm{NH}_{4}{ }^{+}-\mathrm{N}$ deposition in different months showed the same pattern as precipitation. Bulk $\mathrm{Nr}$ deposition mainly occurred from March to October, accounting for 96.2 percent of total annual $\mathrm{NO}_{3}{ }^{-}-\mathrm{N}$ deposition and 97.2 percent of annual $\mathrm{NH}_{4}{ }^{+}-\mathrm{N}$ deposition. Monthly bulk deposition of $\mathrm{NO}_{3}{ }^{-}-\mathrm{N}^{-}$and $\mathrm{NH}_{4}{ }^{+}-\mathrm{N}$ ranged from $0.01-0.23 \mathrm{~kg} \mathrm{~N} \mathrm{ha}^{-1}$ and $0.01-0.28 \mathrm{~kg} \mathrm{~N} \mathrm{ha}^{-1}$, respectively (Figure $2 \mathrm{~b}, \mathrm{c}$ ).

\subsection{Variations in the Monthly Volume Weighted $M e a n \mathrm{NO}_{3}{ }^{-}$and $\mathrm{NH}_{4}{ }^{+}$Concentrations and Their Relationship}

Monthly volume-weighted mean concentrations of both $\mathrm{NO}_{3}{ }^{-}$and $\mathrm{NH}_{4}{ }^{+}$showed similar patterns of high in winter and low in summer, with little variation from March to September. Monthly concentrations of $\mathrm{NO}_{3}{ }^{-}$and $\mathrm{NH}_{4}{ }^{+}$were in the range of $0.12-0.39$ and $0.16-0.38 \mathrm{mg} \mathrm{L}^{-1}$, respectively (Figure 3a,b). In order to understand the predominant $\mathrm{Nr}$ deposition forms in different months, monthly concentrations of both $\mathrm{NO}_{3}{ }^{-}$and $\mathrm{NH}_{4}{ }^{+}$were used in a linear fitting procedure. The result revealed that monthly $\mathrm{NO}_{3}{ }^{-}$and $\mathrm{NH}_{4}{ }^{+}$concentrations in precipitation are positively significantly correlated $\left(\mathrm{R}^{2}=0.951\right)$ (Figure 3c), and the dominant $\mathrm{Nr}$ form shifted from $\mathrm{NH}_{4}{ }^{+}$to $\mathrm{NO}_{3}{ }^{-}$ as the bulk $\mathrm{Nr}$ concentration increased. 

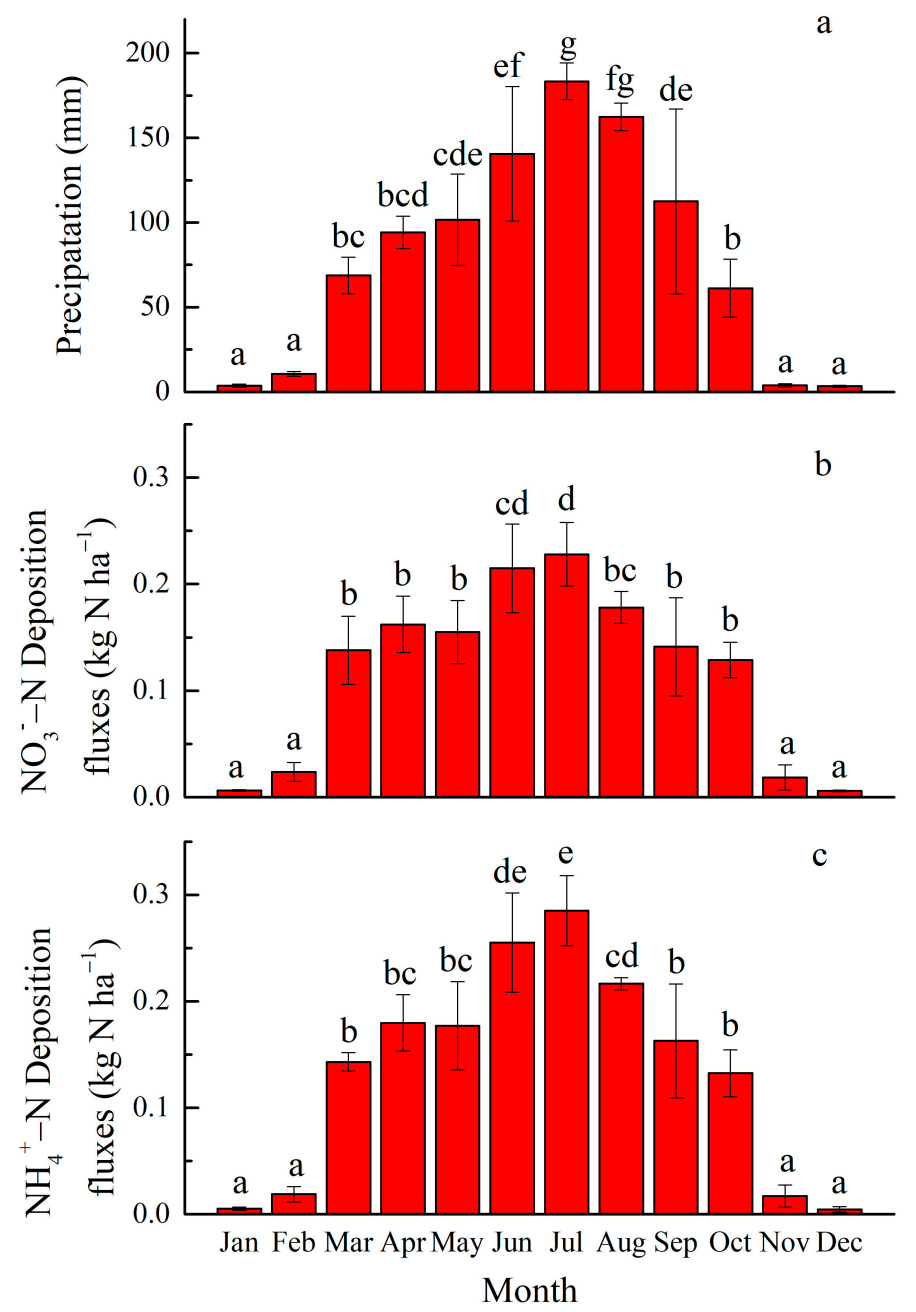

Figure 2. Variation of monthly precipitation amount (a), $\mathrm{NO}_{3}{ }^{-}$(b) and $\mathrm{NH}_{4}{ }^{+}$(c) deposition. Different letters above the error bar means that the difference reaches a significant level. Correspondingly, the same letters exists above the error bar that means the difference is insignificant.

\subsection{Variation in the Monthly Atmospheric $\mathrm{NO}_{2}$ and $\mathrm{NH}_{3}$ Concentrations}

Monthly mean concentrations of atmospheric $\mathrm{NO}_{2}$ and $\mathrm{NH}_{3}$ were in the ranges of $0.79-1.13$ and $1.15-3.53 \mathrm{mg} \mathrm{N} \mathrm{L}^{-1}$, respectively (Figure 4). There was no obvious trend of monthly atmospheric $\mathrm{NO}_{2}$ concentrations throughout the year. In contrast, atmospheric $\mathrm{NH}_{3}$ concentrations increased from January to May and then decreased from August to December. The highest $\mathrm{NH}_{3}$ concentrations occurred from March to August, corresponding to the plant growing season.

\subsection{Annual Trends in Atmospheric Nr Concentrations and Bulk Deposition}

Atmospheric Nr concentrations increased from 2016 to 2019, being 3.11, 2.79, 3.52 and $3.62 \mu \mathrm{g} \mathrm{N} \mathrm{m}^{-3}$ in 2016, 2017, 2018 and 2019, respectively (Figure 5a). $\mathrm{NH}_{3}$ was the dominant $\mathrm{Nr}$ species during the experimental period, with concentrations of 2.20, 1.98, 2.55 and $2.63 \mu \mathrm{g} \mathrm{N} \mathrm{m}^{-3}$ in 2016, 2017, 2018 and 2019, respectively. 


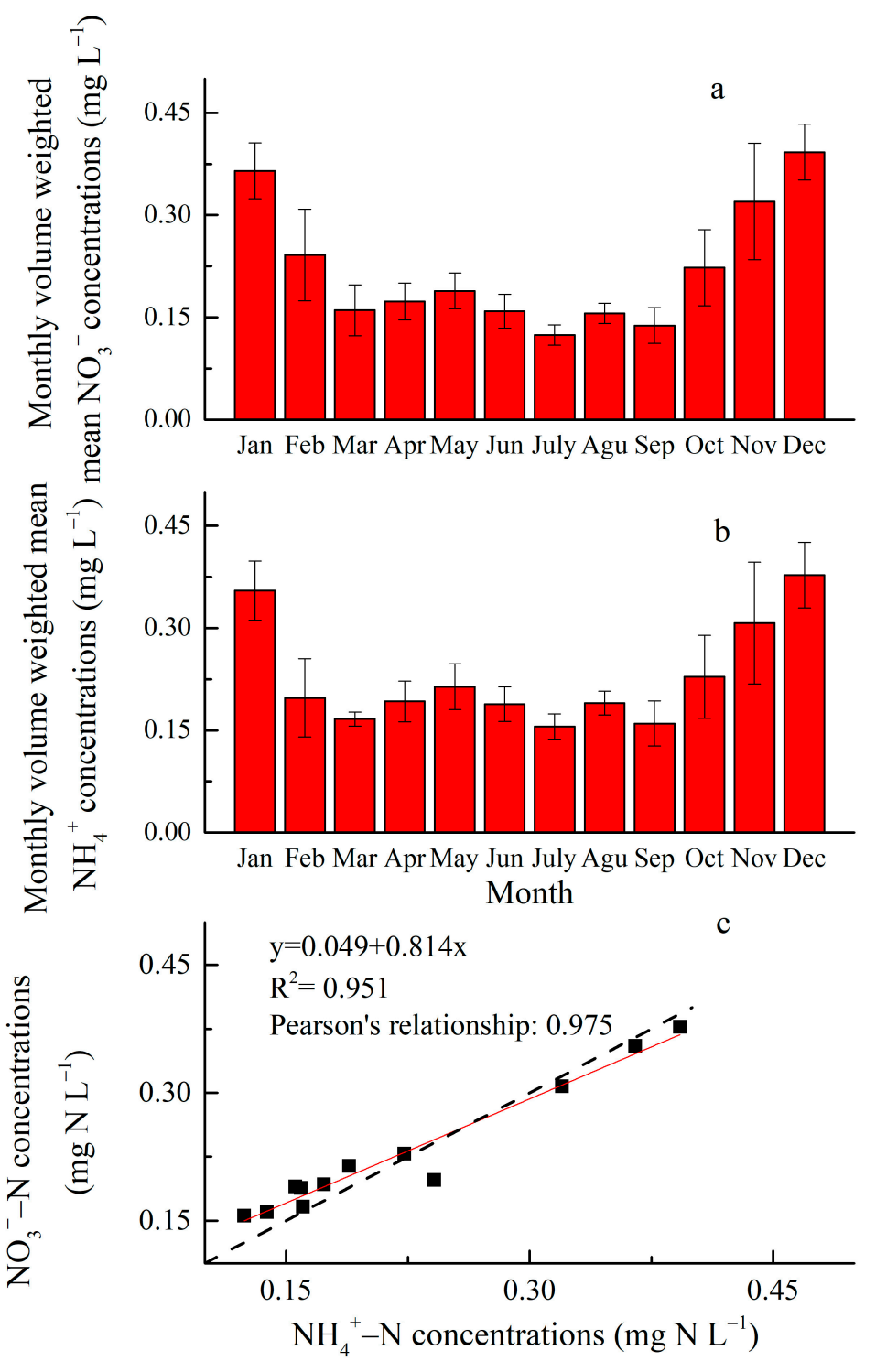

Figure 3. Variation in the monthly volume-weighted mean $\mathrm{NO}_{3}{ }^{-}$(a) and $\mathrm{NH}_{4}{ }^{+}$(b) concentrations and their relationship (c). In (c), the dashed line shows when the $\mathrm{NO}_{3}{ }^{-}$concentration is equal to the $\mathrm{NH}_{4}{ }^{+}$concentration in precipitation. Black squares above the dashed line mean that $\mathrm{NH}_{4}{ }^{+}-\mathrm{N}$ was the predominant $\mathrm{N}$ deposition form. Black squares represent the monthly volume weight mean $\mathrm{Nr}$ concentration; the red line represents the fitting line.

Bulk Nr deposition was 2.91, 3.14, 2.85 and $3.09 \mathrm{~kg} \mathrm{~N} \mathrm{ha}^{-1} \mathrm{y}^{-1}$ in 2016, 2017, 2018 and 2019, respectively (Figure $5 \mathrm{~b}$ ). $\mathrm{NH}_{4}{ }^{+}-\mathrm{N}$ was the dominant species, its deposition being 1.56, 1.70, 1.51 and $1.62 \mathrm{~kg} \mathrm{~N} \mathrm{ha}^{-1} \mathrm{y}^{-1}$ in 2016, 2017, 2018 and 2019, respectively.

Annual dry deposition of $\mathrm{NH}_{3}$ and $\mathrm{NO}_{2}$ was calculated from their deposition velocities multiplied by their concentrations. In 2016, 2017, 2018 and 2019, the deposition of $\mathrm{NH}_{3}$ was 1.11, 1.00, 1.29 and $1.33 \mathrm{~kg} \mathrm{~N} \mathrm{ha}^{-1} \mathrm{y}^{-1}$, respectively, and of $\mathrm{NO}_{2}$ was $0.05,0.04,0.05$ and $0.05 \mathrm{~kg} \mathrm{~N} \mathrm{ha}^{-1} \mathrm{y}^{-1}$, respectively.

The average total annual $\mathrm{Nr}$ deposition (bulk plus dry) was $4.23(3.00+1.23) \mathrm{kg} \mathrm{N} \mathrm{ha}^{-1} \mathrm{y}^{-1}$. Reduced nitrogen was dominant, accounting for 65.7 percent of the total deposition. The percentage of reduced nitrogen was very high in the dry deposition, being 96.1 percent of the annual dry $\mathrm{Nr}$ deposition. 

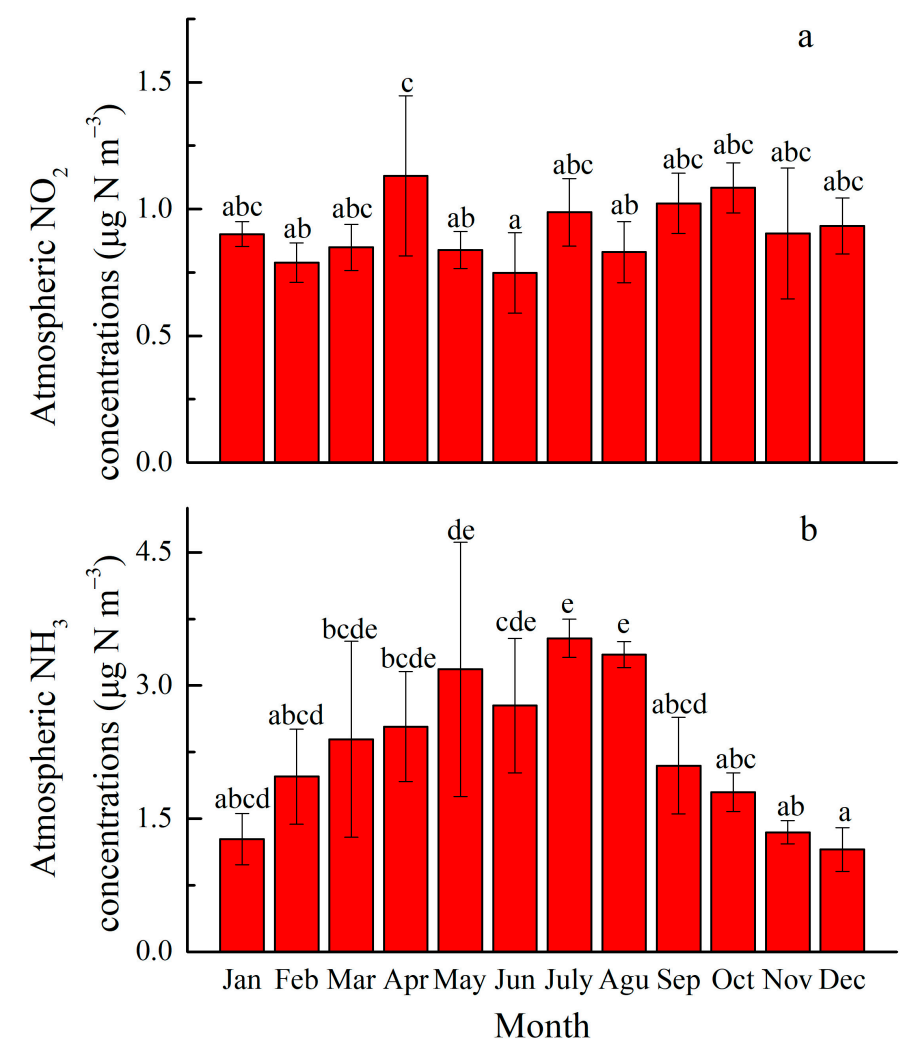

Figure 4. Variation in monthly atmospheric $\mathrm{NO}_{2}(\mathbf{a})$ and $\mathrm{NH}_{3}(\mathbf{b})$ concentrations. Different letters above the error bar means that the difference reaches a significant level. Correspondingly, the same letters exists above the error bar that means the difference is insignificant.

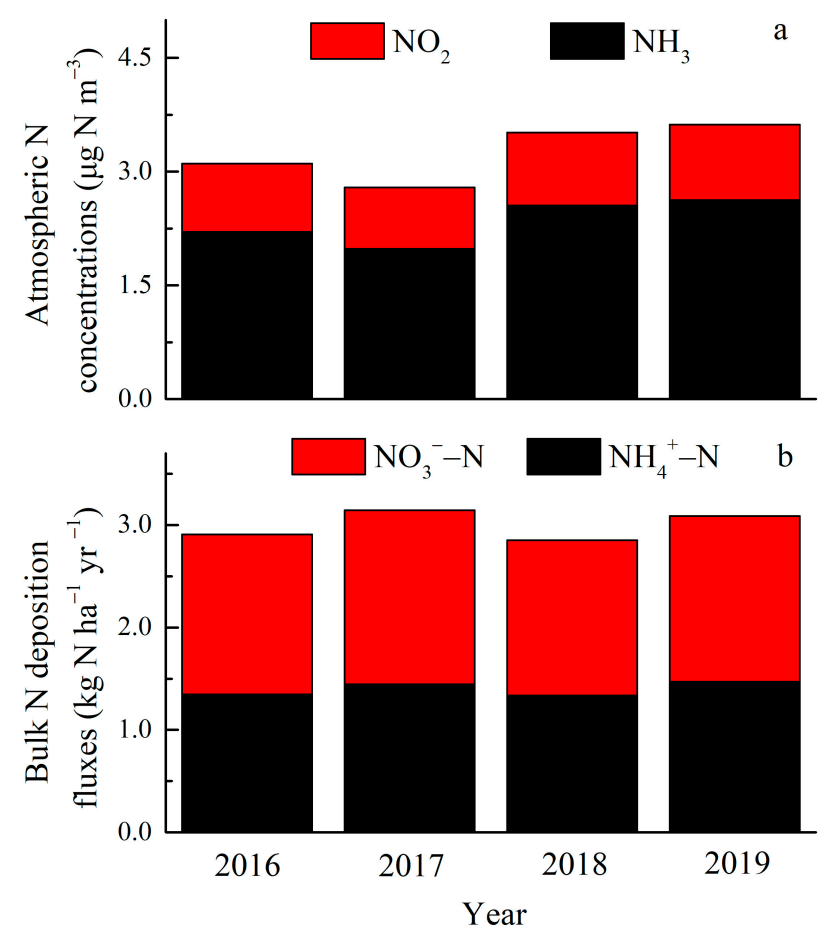

Figure 5. Annual trends in atmospheric $\mathrm{Nr}$ concentrations (a) and bulk $\mathrm{Nr}$ deposition (b). 


\section{Discussion}

\subsection{Bulk Nr Deposition and Monthly Precipitation}

Bulk Nr deposition was determined from precipitation amount and $\mathrm{Nr}$ concentrations in precipitation [28]. We found that $\mathrm{Nr}$ deposition was mainly controlled by precipitation, increasing with precipitation. It has been reported that $\mathrm{Nr}$ deposition is logarithmically related to precipitation amount because atmospheric $\mathrm{NH}_{4}{ }^{+}$and $\mathrm{NO}_{3}{ }^{-}$are scavenged by rainfall, and scavenging decreases as rainfall intensity, duration and amount increases [31]. At our site, the relationship between precipitation amount and $\mathrm{Nr}$ deposition fitted both linear and logarithmic equations. However, with a linear relationship for both $\mathrm{NH}_{4}{ }^{+}$and $\mathrm{NO}_{3}{ }^{-}$giving the better fit (Figure 6a,b). This could be because atmospheric $\mathrm{NH}_{4}{ }^{+}$and $\mathrm{NO}_{3}{ }^{-}$concentrations were both so low as to be almost unaffected by rainfall intensity, duration and amount. Although we could not measure gaseous/particulate $\mathrm{NH}_{4}{ }^{+}$and $\mathrm{NO}_{3}{ }^{-}$concentrations because of limited technical resources, the low $\mathrm{NH}_{3}$ and $\mathrm{NO}_{2}$ concentrations support this idea to some extent (Figure $4 a, b$ ). Overall, precipitation amount was the dominant factor determining $\mathrm{Nr}$ deposition, both $\mathrm{Nr}$ deposition and precipitation showing similar patterns of monthly variation.

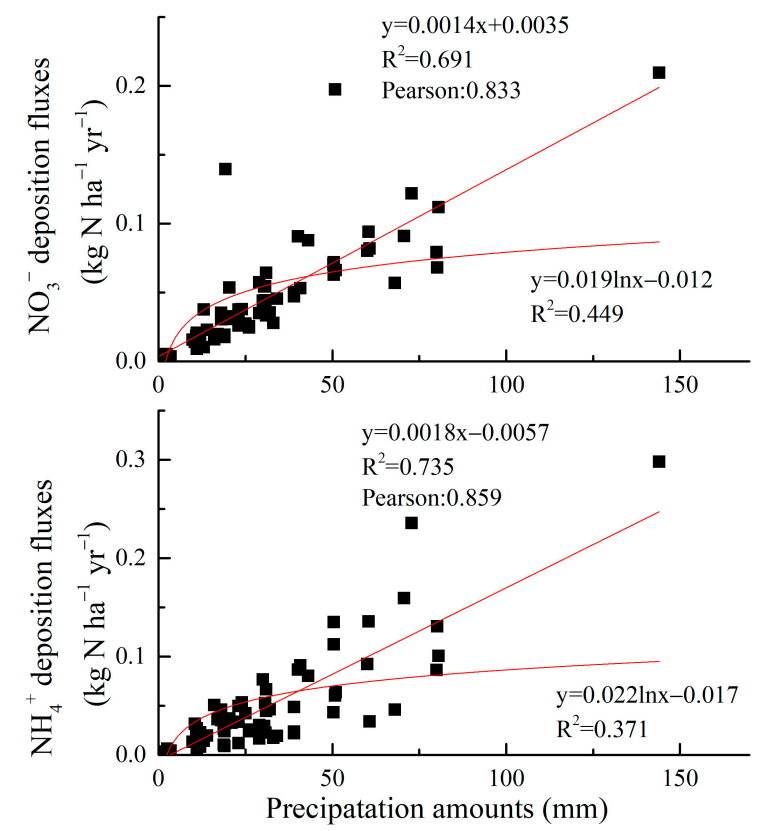

Figure 6. Linear and logarithmic relationships between precipitation and $\mathrm{NO}_{3}^{-}$(a) and $\mathrm{NH}_{4}{ }^{+}$ (b) concentrations. Black squares represent the $\mathrm{Nr}$ concentration in each precipitation sample; the red line represents the fitting line.

\subsection{Variation of Monthly Bulk Nr Concentrations and Atmospheric Nr Concentrations}

Bulk Nr concentrations are usually inversely correlated with precipitation amount [28]. We found this, with high concentrations of both $\mathrm{NH}_{4}{ }^{+}$and $\mathrm{NO}_{3}{ }^{-}$in November to February when precipitation amounts were relatively low (Figure 2a and (Figure 3a,b). This trend could have been amplified by the collection of some dry deposition (e.g., dust) in the continuously open precipitation gauges, which would have had the biggest effect when precipitation was low. Monthly variation of $\mathrm{NH}_{4}{ }^{+}$ concentrations in precipitation was comparatively less than those of both precipitation amount and atmospheric $\mathrm{NH}_{3}$ concentrations from January to September. Both atmospheric $\mathrm{NH}_{3}$ concentrations and precipitation amounts were high in Spring and Summer (Figure 2a and (Figure 3b). However, bulk $\mathrm{NH}_{4}{ }^{+}$concentrations were not low, i.e., not diluted by large amounts of precipitation, because of high atmospheric $\mathrm{NH}_{3}$ concentrations. However, the dominant $\mathrm{Nr}$ species in precipitation changed from 
$\mathrm{NH}_{4}{ }^{+}$to $\mathrm{NO}_{3}{ }^{-}$as bulk $\mathrm{Nr}$ concentrations increased (Figure 3c). Low monthly bulk Nr concentrations mainly occurred in spring and summer.

$\mathrm{NH}_{3}$ emissions are usually the largest in summer due to intensive agricultural activities and higher temperatures [32]. Atmospheric $\mathrm{NH}_{3}$ concentrations were highest in summer at our site (Figure $4 \mathrm{~b}$ ) and in a range of different ecosystems, as shown by in situ monitoring [23,30]. Ambient $\mathrm{NO}_{2}$ is mainly attributed to industrial sources (e.g., fossil fuel burning; automobile exhausts; power plants), and so is highest in the most populated areas $[33,34]$. Although some research has shown that $\mathrm{NO}_{2}$ exhibits seasonal variation $[29,35]$ because of fossil fuel burning in winter, there were no $\mathrm{NO}_{2}$ pollution sources near our site other than the state road (\#318), and so $\mathrm{NO}_{2}$ concentrations showed little seasonal variation.

\subsection{Reduced and Oxidized Nitrogen Deposition in Bulk and Dry Deposition}

Du et al. reported that $\mathrm{NH}_{4}{ }^{+}$dominated bulk $\mathrm{Nr}$ deposition in forest ecosystems in China, with a mean bulk deposition of $9.4 \mathrm{~kg} \mathrm{~N} \mathrm{ha}^{-1} \mathrm{y}^{-1}$ for $\mathrm{NH}_{4}{ }^{+}-\mathrm{N}$ and $3.9 \mathrm{~kg} \mathrm{~N} \mathrm{ha}^{-1} \mathrm{y}^{-1}$ for $\mathrm{NO}_{3}{ }^{-}-\mathrm{N}$ [36]. Our results revealed that both reduced and oxidized nitrogen deposition in this Southeast Tibetan forest ecosystem were much lower than the average bulk $\mathrm{Nr}$ deposition in China, with values of $1.60 \mathrm{~kg} \mathrm{~N} \mathrm{ha}^{-1} \mathrm{y}^{-1}$ for reduced nitrogen and $1.40 \mathrm{~kg} \mathrm{~N} \mathrm{ha}^{-1} \mathrm{y}^{-1}$ for oxidized nitrogen, with reduced nitrogen dominant.

Based on the NitroEurope network, Flechard et al. found that mean concentrations of $\mathrm{NH}_{3}$ and $\mathrm{NO}_{2}$ were 1.03 and $2.15 \mu \mathrm{g} \mathrm{N} \mathrm{m}{ }^{-3}$ in forest ecosystems in Europe [10]. We measured $\mathrm{NH}_{3}$ and $\mathrm{NO}_{2}$ concentrations of 2.34 and $0.92 \mu \mathrm{g} \mathrm{N} \mathrm{m}{ }^{-3}$, respectively. Atmospheric $\mathrm{NH}_{3}$ concentrations in southeast Tibet were, therefore, higher than the average in Europe, but those of $\mathrm{NO}_{2}$ lower. This is not surprising because the Tibetan forest is in a remote area, surrounded by dense primordial forest. Low $\mathrm{NO}_{2}$ concentrations can be attributed to the fact that atmospheric Nr sources are mostly natural.

High atmospheric $\mathrm{NH}_{3}$ concentrations can be explained by fog events that frequently occur in the research area, resulting in high $\mathrm{NH}_{4}{ }^{+}$concentrations [37]. Average atmospheric $\mathrm{NH}_{3}$ and $\mathrm{NO}_{2}$ concentrations across China are 6.1 and $6.8 \mu \mathrm{g} \mathrm{N} \mathrm{m}^{-3}$ [28], almost 2.6 and 7.4 times than those in our research area, respectively.

Clearly, the atmosphere in the southeast Tibetan forest is relatively "clean", especially for $\mathrm{NO}_{2}$. However, ammonia is likely to be more ecologically and biologically toxic than oxidized species [38,39], and the annual deposition of reduced nitrogen was higher than that of oxidized nitrogen. Therefore, this southeast boreal forest ecosystem could be threatened by $\mathrm{Nr}$ deposition dominated by reduced species.

\subsection{Comparison of Nr Deposition and Potential Ecological Effects with Other Regions}

It is interesting to compare the current $\mathrm{Nr}$ deposition to this southeast Tibetan forest ecosystem with bulk deposition to other forest ecosystems around the world published in the last decade (Table 1). Clearly, bulk Nr deposition to our site is very low. It has been reported that external $\mathrm{Nr}$ inputs can increase long-term carbon sinks in boreal, temperate and tropical forests $[20,40]$. Thomas reported that forest carbon sequestration was significantly enhanced when $\mathrm{Nr}$ deposition was between 3 and $11 \mathrm{~kg} \mathrm{~N} \mathrm{ha}^{-1} \mathrm{y}^{-1}$ [20]. It had been reported that the critical nitrogen load of deciduous conifers in cold-temperate and temperate mountains was in the range 5-10 (or 10-15) $\mathrm{kg} \mathrm{N} \mathrm{ha}^{-1} \mathrm{y}^{-1}[11,41]$. Considering the low annual $\mathrm{Nr}$ deposition to this Tibetan forest ecosystem, which is lower than the $\mathrm{Nr}$ deposition critical load, the changes of forest net productivity should be given more attention. 
Table 1. Comparison of bulk/wet Nr deposition in a range of forest ecosystems.

\begin{tabular}{|c|c|c|c|c|c|}
\hline Location & $\begin{array}{l}\text { Sampling } \\
\text { Years }\end{array}$ & $\begin{array}{c}\text { Bulk } \mathrm{NH}_{4}{ }^{+} \\
\text {Deposition } \\
\left(\mathrm{kg} \mathrm{N} \mathrm{ha}^{-1} \mathrm{y}^{-1}\right)\end{array}$ & $\begin{array}{c}\text { Bulk } \mathrm{NO}_{3}^{-} \\
\text {Deposition } \\
\left(\mathrm{kg} \mathrm{N} \mathrm{ha}^{-1} \mathrm{y}^{-1}\right)\end{array}$ & $\begin{array}{l}\text { Bulk Inorganic } \\
\mathrm{Nr} \text { Deposition } \\
\left(\mathrm{kg} \mathrm{N} \mathrm{ha}^{-1} \mathrm{y}^{-1}\right)\end{array}$ & References \\
\hline $\begin{array}{l}\text { Wuyi Mountains } \\
\text { (Fujian Province) }\end{array}$ & 2014-2015 & & 20.2 & & [42] \\
\hline $\begin{array}{l}\text { Shitai county } \\
\text { (Anhui Province) }\end{array}$ & 2014-2015 & 9.24 & 10.5 & 27.7 & [43] \\
\hline $\begin{array}{l}\text { Lingyan Mountain } \\
\text { (Sichuan Province) }\end{array}$ & 2015-2016 & 16.4 & 10.0 & 26.4 & [44] \\
\hline $\begin{array}{l}\text { Tiantong Mountain } \\
\text { (Zhejiang Province) }\end{array}$ & 2011-2013 & 10.4 & 8.49 & 18.9 & [45] \\
\hline $\begin{array}{l}\text { Jigong Mountain } \\
\text { (Henan Province) }\end{array}$ & 2014-2015 & 7.90 & 7.60 & 15.5 & [29] \\
\hline $\begin{array}{l}\text { Shengnongjia Mountain } \\
\text { (Hubei Province) }\end{array}$ & 2015 & 5.24 & 6.65 & 11.98 & [46] \\
\hline $\begin{array}{l}\text { Fuji Mountain } \\
\text { Japan }\end{array}$ & & & & 8.04 & [47] \\
\hline $\begin{array}{l}\text { Heihe Tianlaochi } \\
\text { (Gansu Province) }\end{array}$ & 2015 & 0.30 & 5.55 & 5.85 & [48] \\
\hline $\begin{array}{l}\text { Tianmu Mountain } \\
\text { (Zhejiang Province) }\end{array}$ & 2013-2014 & & & 5.25 & [49] \\
\hline $\begin{array}{l}\text { Sejila Mountain } \\
\text { (Tibet Autonomous Region) }\end{array}$ & 2016-2019 & 1.60 & 1.40 & 3.00 & This Study \\
\hline Switzerland & 2014 & $1.04-10.7$ & $1.55-6.86$ & $2.58-17.56$ & [50] \\
\hline $\begin{array}{l}17 \text { forest sites } \\
\text { (Swiss) }\end{array}$ & 2014 & $1.00-10.7$ & $1.40-8.60$ & $2.40-18.4$ & [9] \\
\hline East of England & 2005-2010 & & & $6.6-13.8$ & [51] \\
\hline European forests & $2010-2020$ & & & $>6.5$ & [52] \\
\hline $\begin{array}{l}\text { Gongga Mountain } \\
\text { (Sichuan Province) }\end{array}$ & 2008-2011 & $3.17-4.80$ & $1.66-3.00$ & & [53] \\
\hline $\begin{array}{l}\text { Spanish forests } \\
\text { (Spain) }\end{array}$ & 2011-2013 & & & $2.42-6.83$ & [34] \\
\hline $\begin{array}{l}\text { Loch Vale } \\
\text { Colorado }\end{array}$ & 2010-2017 & & & $2.52-4.58$ & [54] \\
\hline
\end{tabular}

\subsection{Implications and Uncertainty Analysis}

Although bulk $\mathrm{Nr}$ deposition was more precisely measured than dry $\mathrm{Nr}$ deposition, there are errors in the former. For example, both $\mathrm{NO}_{3}{ }^{-}$and $\mathrm{NH}_{4}{ }^{+}$in precipitation are absorbed by the forest canopy, especially in lower $\mathrm{Nr}$ deposition regions [9]. Additionally, total bulk $\mathrm{Nr}$ deposition is underestimated when dissolved organic nitrogen (DON) is not measured, as was the case in this work. Izquieta-Rojano et al. reported that the contribution of DON to total bulk Nr deposition ranged from $34 \%$ to $56 \%$ in forest ecosystems [55].

For dry deposition, deposition velocities are influenced by several factors and vary across ecosystems $[9,10]$. The deposition velocity of $\mathrm{NH}_{3}$ is often overestimated in forest ecosystems because $\mathrm{NH}_{3}$ exchange to foliar surfaces is bidirectional, so $\mathrm{NH}_{3}$ deposition can be overestimated. Due to poor technical resources at our research site, we could not estimate the actual $\mathrm{Nr}$ deposition velocities of different $\mathrm{Nr}$ species. We used deposition velocities of $\mathrm{NH}_{3}$ and $\mathrm{NO}_{2}$ to "background environments" across China to calculate $\mathrm{Nr}$ deposition $\left(\mathrm{NH}_{3}: 0.47 \mathrm{~cm} \mathrm{~s}^{-1} ; \mathrm{NO}_{2}: 0.17 \mathrm{~cm} \mathrm{~s}^{-1}\right)$ [28], making the deposition of $\mathrm{NH}_{3}$ and $\mathrm{NO}_{2} 0.33$ and $0.05 \mathrm{~kg} \mathrm{~N} \mathrm{ha}^{-1} \mathrm{y}^{-1}$, respectively. Reduced nitrogen deposition still dominates.

Flechard et al. reported that the percentages of $\mathrm{NH}_{3}$ in total dry reduced nitrogen deposition and $\mathrm{NO}_{2}$ in total dry oxidized nitrogen deposition were $77.4 \%$ and $21.1 \%$ [10], respectively. Clearly, $\mathrm{NH}_{3}$ was the dominant species in dry reduced nitrogen deposition, but $\mathrm{NO}_{2}$ was not so important in dry oxidized nitrogen deposition. Dry deposition of $\mathrm{NH}_{3}$ and $\mathrm{NO}_{2}$ were 1.18 and $0.05 \mathrm{~kg} \mathrm{~N} \mathrm{ha}^{-1} \mathrm{y}^{-1}$ in our research area. We used these percentages $(77.4 \%$ and $21.1 \%)$ to convert $\mathrm{NO}_{2}$ deposition to total oxidized nitrogen deposition and $\mathrm{NH}_{3}$ deposition to total reduced nitrogen deposition giving values of total reduced nitrogen and oxidized nitrogen of 1.52 and $0.24 \mathrm{~kg} \mathrm{~N} \mathrm{ha}^{-1} \mathrm{y}^{-1}$, respectively. Reduced nitrogen was the dominant $\mathrm{Nr}$ deposition species in this southeast Tibet forest ecosystem. 


\section{Conclusions}

Based on four years of continuous monitoring, we found that $\mathrm{Nr}$ deposition was small in a southeast Tibet boreal forest. Average concentrations of atmospheric $\mathrm{NH}_{3}$ and $\mathrm{NO}_{2}$ were 2.34 and $0.90 \mu \mathrm{g} \mathrm{N} \mathrm{m}{ }^{-3}$, respectively. Bulk deposition of $\mathrm{NH}_{4}{ }^{+}$and $\mathrm{NO}_{3}{ }^{-}$was 1.60 and $1.40 \mathrm{~kg} \mathrm{~N} \mathrm{ha}^{-1} \mathrm{y}^{-1}$, respectively. Nitrogen deposition showed a clear seasonal variation-high in summer and low in winter-dependent on the monthly variation in precipitation. Additionally, atmospheric $\mathrm{NH}_{4}{ }^{+}$concentrations were high in summer and low in winter. Annual $\mathrm{Nr}$ deposition was less than the critical load (5-10 kg N ha $\left.{ }^{-1} \mathrm{y}^{-1}\right)$, being $4.23 \mathrm{~kg} \mathrm{~N} \mathrm{ha}^{-1} \mathrm{y}^{-1}$ and dominated by reduced nitrogen. Deposition was mainly concentrated in the months of plant growth. As a result, carbon sequestration and net productivity in this southeast Tibet boreal forest ecosystem deserve more research because these regions may benefit from slightly increased $\mathrm{Nr}$ deposition. More comprehensive methods, as used in $\mathrm{Nr}$ deposition monitoring, should be employed in these regions sensitive to global change.

Author Contributions: All authors contributed a lot. Conceptualization, X.L. and W.W.; software, W.W., L.G.; validation, X.L.; formal analysis, W.W., Z.W., X.M.; investigation, W.W., L.G.; resources, W.W., J.F., X.L.; data curation, W.W., Z.W., X.M.; writing-original draft preparation, W.W. and L.G.; writing-review and editing, W.W., X.L.; visualization, W.W.; supervision, W.W., X.L.; project administration, W.W., X.L.; funding acquisition, W.W., X.L. All authors have read and agreed to the published version of the manuscript.

Funding: This work was funded by the National Natural Science Foundation of China (42067036), China's National Key R\&D projects (2017YFC0210103, DQGG0208), and the Deutsche Forschungsgemeinschaft (DFG, German Research Foundation)-328017493/GRK 2366 (Sino-German International Research Training Group AMAIZE-P). The Natural Science Foundation of Tibet Autonomous Region Department and Agriculture and Animal Husbandry college. Forestry Innovation Team Construction project of Xizang Agriculture and Animal Husbandry College. Key Laboratory of Forest Ecology in Tibet Plateau (Tibet Agriculture and Animal Husbandry University), Ministry of Education. Keith Goulding provided an important contribution to the improvement of the English.

Conflicts of Interest: The authors declare no conflict of interest.

\section{References}

1. Zhang, X.; Davidson, E.A.; Mauzerall, D.L.; Searchinger, T.D.; Dumas, P.; Shen, Y. Managing nitrogen for sustainable development. Nature 2015, 528, 51-59. [CrossRef] [PubMed]

2. Liu, X.J.; Duan, L.; Mo, J.M.; Du, E.Z.; Shen, J.L.; Lu, X.K.; Zhang, Y.; Zhou, X.B.; He, C.N.; Zhang, F.S. Nitrogen deposition and its ecological impact in China: An overview. Environ. Pollut. 2011, 159, 2251-2264. [CrossRef] [PubMed]

3. Cui, S.H.; Shi, Y.L.; Groffman, P.M.; Schlesinger, W.H.; Zhu, Y.G. Centennial-scale analysis of the creation and fate of reactive nitrogen in China (1910-2010). Proc. Natl. Acad. Sci. USA 2013, 110, 2052-2057. [CrossRef] [PubMed]

4. Kulshrestha, U.C.; Kulshrestha, M.J.; Satyanarayana, J.; Reddy, L.A.K. Atmospheric Deposition of Reactive Nitrogen in India; Springer: Dordrecht, The Netherlands, 2014.

5. Yu, G.R.; Jia, Y.L.; He, N.P.; Zhu, J.X.; Chen, Z.; Wang, Q.F.; Piao, S.L.; Liu, X.J.; He, H.L.; Guo, X.B.; et al. Stabilization of atmospheric nitrogen deposition in China over the past decade. Nat. Geosci. 2019, 12, 424-429. [CrossRef]

6. Wen, Z.; Xu, W.; Li, Q.; Han, M.J.; Tang, A.H.; Zhang, Y.; Luo, X.S.; Shen, J.L.; Wang, W.; Li, K.H.; et al. Changes of nitrogen deposition in china from 1980 to 2018. Environ. Int. 2020, 144, 106022. [CrossRef]

7. Du, E. Rise and fall of nitrogen deposition in the United States. Proc. Natl. Acad. Sci. USA 2016, 113, E3594-E3595. [CrossRef]

8. Schwede, D.B.; Simpson, D.; Tan, J.; Fu, J.S.; Dentener, F.; Du, E.; De Vries, W. Spatial variation of modelled total, dry and wet nitrogen deposition to forests at global scale. Environ. Pollut. 2018, 243, 1287-1301. [CrossRef]

9. Thimonier, A.; Kosonen, Z.; Braun, S.; Rihm, B.; Schleppi, P.; Schmitt, M.; Seitler, E.; Waldner, P.; Thoni, L. Total deposition of nitrogen in Swiss forests: Comparison of assessment methods and evaluation of changes over two decades. Atmos. Environ. 2019, 198, 335-350. [CrossRef] 
10. Flechard, C.R.; Nemitz, E.; Smith, R.I.; Fowler, D.; Vermeulen, A.T.; Bleeker, A.; Erisman, J.W.; Simpson, D.; Zhang, L.; Tang, Y.S.; et al. Dry deposition of reactive nitrogen to European ecosystems: A comparison of inferential models across the NitroEurope network. Atmos. Chem. Phys. 2011, 11, 2703-2728. [CrossRef]

11. Xie, D.; Zhao, B.; Wang, S.; Duan, L. Benefit of China's reduction in nitrogen oxides emission to natural ecosystems in East Asia with respect to critical load exceedance. Environ. Int. 2020, 136, 1054-1068. [CrossRef]

12. Du, E.; De Vries, W.; Han, W.; Liu, X.; Yan, Z.; Jiang, Y. Imbalanced phosphorus and nitrogen deposition in China's forests. Atmos. Chem. Phys. 2016, 16, 8571-8579. [CrossRef]

13. Schulte-Uebbing, L.; de Vries, W. Global-scale impacts of nitrogen deposition on tree carbon sequestration in tropical, temperate, and boreal forests: A meta-analysis. Glob. Chang. Biol. 2018, 24, 416-431. [CrossRef] [PubMed]

14. Tian, D.; Du, E.; Jiang, L.; Ma, S.; Zeng, W.; Zou, A.; Feng, C.; Xu, L.; Xing, A.; Wang, W.; et al. Responses of forest ecosystems to increasing N deposition in China: A critical review. Environ. Pollut. 2018, 243, 75-86. [CrossRef] [PubMed]

15. Zhao, Y.; Zhang, L.; Chen, Y.; Liu, X.; Xu, W.; Pan, Y.; Duan, L. Atmospheric nitrogen deposition to china: A model analysis on nitrogen budget and critical load exceedance. Atmos. Environ. 2017, 153, 32-40. [CrossRef]

16. Fang, Y.T.; Yoh, M.; Koba, K.; Zhu, W.X.; Takebayashi, Y.; Xiao, Y.H.; Lei, C.Y.; Mo, J.M.; Zhang, W.; $\mathrm{Lu}, \mathrm{X} . \mathrm{K}$. Nitrogen deposition and forest nitrogen cycling along an urban-rural transect in southern China. Glob. Chang. Biol. 2011, 17, 872-885. [CrossRef]

17. Yu, Q.; Duan, L.; Yu, L.; Chen, X.; Si, G.; Ke, P.; Ye, Z.; Mulder, J. Threshold and multiple indicators for nitrogen saturation in subtropical forests. Environ. Pollut. 2018, 241, 664-673. [CrossRef]

18. Boyle, E. Nitrogen pollution knows no bounds. Science 2017, 356, 700-701. [CrossRef]

19. Hogberg, P. Environmental science-Nitrogen impacts on forest carbon. Nature 2007, 447, 781-782. [CrossRef]

20. Thomas, R.Q.; Canham, C.D.; Weathers, K.C.; Goodale, C.L. Increased tree carbon storage in response to nitrogen deposition in the US. Nat. Geosci. 2010, 3, 13-17. [CrossRef]

21. Zong, N.; Shi, P.L.; Song, M.H.; Zhang, X.Z.; Jiang, J.; Chai, X. Nitrogen Critical Loads for an Alpine Meadow Ecosystem on the Tibetan Plateau. Environ. Manag. 2016, 57, 531-542.

22. Han, Y.H.; Dong, S.K.; Zhao, Z.Z.; Sha, W.; Li, S.; Shen, H.; Xiao, J.N.; Zhang, J.; Wu, X.Y.; Jiang, X.M.; et al. Response of soil nutrients and stoichiometry to elevated nitrogen deposition in alpine grassland on the Qinghai-Tibetan Plateau. Geoderma 2019, 343, 263-268. [CrossRef]

23. Wang, W.; Xu, W.; Wen, Z.; Wang, D.; Wang, S.; Zhang, Z.; Zhao, Y.; Liu, X. Characteristics of Atmospheric Reactive Nitrogen Deposition in Nyingchi City. Sci. Rep. 2019, 9, 4645. [CrossRef] [PubMed]

24. Zhu, J.X.; He, N.P.; Wang, Q.F.; Yuan, G.F.; Wen, D.; Yu, G.R.; Jia, Y.L. The composition, spatial patterns, and influencing factors of atmospheric wet nitrogen deposition in Chinese terrestrial ecosystems. Sci. Total Environ. 2015, 511, 777-785. [CrossRef] [PubMed]

25. Liu, Y.W.; Xu, R.; Wang, Y.S.; Pan, Y.P.; Piao, S.L. Wet deposition of atmospheric inorganic nitrogen at five remote sites in the Tibetan Plateau. Atmos. Chem. Phys. 2015, 15, 11683-11700. [CrossRef]

26. He, Z.H. Modeling Forest NPP Patterns on the Tibetan Plateau and its Responses to Climate Change. Master's Thesis, Chinese Academy of Forestry, Beijing, China, 2008. (In Chinese).

27. Zhu, J.X.; Wang, Q.F.; He, N.P.; Smith, M.D.; Elser, J.J.; Du, J.Q.; Yuan, G.F.; Yu, G.R.; Yu, Q. Imbalanced atmospheric nitrogen and phosphorus depositions in China: Implications for nutrient limitation. J. Geophys. Res-Biogeo. 2016, 121, 1605-1616. [CrossRef]

28. Xu, W.; Luo, X.S.; Pan, Y.P.; Zhang, L.; Tang, A.H.; Shen, J.L.; Zhang, Y.; Li, K.H.; Wu, Q.H.; Yang, D.W.; et al. Quantifying atmospheric nitrogen deposition through a nationwide monitoring network across China. Atmos. Chem. Phys. 2015, 15, 12345-12360. [CrossRef]

29. Fu, Y.; Wang, W.; Han, M.; Kuerban, M.; Wang, C.; Liu, X. Atmospheric dry and bulk nitrogen deposition to forest environment in the North China Plain. Atmos. Pollut. Res. 2019, 10, 1636-1642. [CrossRef]

30. Shen, J.L.; Li, Y.; Liu, X.J.; Luo, X.S.; Tang, H.; Zhang, Y.Z.; Wu, J.S. Atmospheric dry and wet nitrogen deposition on three contrasting land use types of an agricultural catchment in subtropical central China. Atmos. Environ. 2013, 67, 415-424. [CrossRef]

31. Zhao, X.; Yan, X.Y.; Xiong, Z.Q.; Xie, Y.X.; Xing, G.X.; Shi, S.L.; Zhu, Z.L. Spatial and Temporal Variation of Inorganic Nitrogen Wet Deposition to the Yangtze River Delta Region, China. Water Air Soil Poll. 2009, 203, 277-289. [CrossRef] 
32. Kang, Y.N.; Liu, M.X.; Song, Y.; Huang, X.; Yao, H.; Cai, X.H.; Zhang, H.S.; Kang, L.; Liu, X.J.; Yan, X.Y.; et al. High-resolution ammonia emissions inventories in China from 1980 to 2012. Atmos. Chem. Phys. 2016, 16, 2043-2058. [CrossRef]

33. Al-Khashman, O.A. Chemical characteristics of rainwater collected at a western site of Jordan. Atmos. Res. 2009, 91, 53-61. [CrossRef]

34. Garcia-Gomez, H.; Izquieta-Rojano, S.; Aguillaume, L.; Gonzalez-Fernandez, I.; Valino, F.; Elustondo, D.; Santamaria, J.M.; Avila, A.; Fenn, M.E.; Alonso, R. Atmospheric deposition of inorganic nitrogen in Spanish forests of Quercus ilex measured with ion-exchange resins and conventional collectors. Environ. Pollut. 2016, 216, 653-661. [CrossRef] [PubMed]

35. Liu, M.Y.; Lin, J.T.; Wang, Y.C.; Sun, Y.; Zheng, B.; Shao, J.Y.; Chen, L.L.; Zheng, Y.X.; Chen, J.X.; Fu, T.M.; et al. Spatiotemporal variability of NO2 and PM25 over Eastern China: Observational and model analyses with a novel statistical method. Atmos. Chem. Phys. 2018, 18, 12933-12952. [CrossRef]

36. Du, E.; Jiang, Y.; Fang, J.Y.; de Vries, W. Inorganic nitrogen deposition in China's forests: Status and characteristics. Atmos. Environ 2014, 98, 474-482. [CrossRef]

37. Wang, W.; Xu, W.; Collett, J.L., Jr.; Liu, D.; Zheng, A.; Dore, A.J.; Liu, X. Chemical compositions of fog and precipitation at Sejila Mountain in the southeast Tibetan Plateau, China. Environ. Pollut. 2019, 253, 560-568. [CrossRef]

38. Hunova, I.; Kurfurst, P.; Stranik, V.; Modlik, M. Nitrogen deposition to forest ecosystems with focus on its different forms. Sci. Total Environ. 2017, 575, 791-798. [CrossRef]

39. van den Berg, L.J.; Jones, L.; Sheppard, L.J.; Smart, S.M.; Bobbink, R.; Dise, N.B.; Ashmore, M.R. Evidence for differential effects of reduced and oxidised nitrogen deposition on vegetation independent of nitrogen load. Environ. Pollut. 2016, 208, 890-897. [CrossRef]

40. Lu, X.Q.; Liu, Y.; Liu, L.; Zhang, Z.; Hu, F.L.; Liu, X.Y.; Sun, X.C. Rainfall partitioning and associated nitrate and sulfate fluxes along a slope gradient in a subtropical broadleaved forest. J. Hydrol. 2020, 591, 125584. [CrossRef]

41. Liu, L. Characteristics of Precipitation Portioning and Chemistry in Subtropical Evergreen Broadleaved Forest. Master's Thesis, Anhui Agricultural University, Hefei, China, 2016. (In Chinese).

42. Yang, K.J.; Yang, W.Q.; Zhuang, L.Y. Characteristics of atmospheric wet nitrogen deposition in Dujiangyan, western edge of Sichuan Basin, China. J. Appl. Environ. Biol. 2018, 24, 107-111. (In Chinese)

43. Li, D.D.; Su, Y.Q.; Zhou, T.Y.; Tao, Z.Y.; Zheng, Z.M.; Wang, X.H. Application of ion exchange resin method on the observation of wet nitrogen deposition fluxes inside and outside Tiantong forest. J. East China Norm. Univ. 2015, 6, 117-125. (In Chinese)

44. Yang, L.; Wang, M.; Wang, C.H. Nitrogen and phosphorous characteristics of canopy rainfall of eight dominant tree species in secondary forests of Shennongiia Moutain. Chin. J. Appl. Ecol. 2018, 37, 1018-1025.

45. Matsumoto, K.; Ogawa, T.; Ishikawa, M.; Hirai, A.; Watanabe, Y.; Nakano, T. Organic and inorganic nitrogen deposition on the red pine forests at the northern foot of Mt. Fuji, Japan. Atmos. Environ. 2020, 237, 117676. [CrossRef]

46. Zhao, Y.M.; Gao, J.T.; Gao, C.C.; Zhao, C.Y.; Ye, M. Ecohydrology and chemical characteristics of typical forests in the Tianlaochi catchment of the Heihe River Basin. Acta Ecol. Sin. 2017, 37, 4636-4645. (In Chinese)

47. Zheng, S.W. Study on the Hydrologic Characteristics of Forest Ecosystem under the Background of Atmospheric Nitrogen Deposition in Tianmu Mountain. Master's Thesis, Zhejiang A\&F University, Hangzhou, China, 2016. (In Chinese).

48. Kosonen, Z.; Schnyder, E.; Hiltbrunner, E.; Thimonier, A.; Schmitt, M.; Seitler, E.; Thöni, L. Current atmospheric nitrogen deposition still exceeds critical loads for sensitive, semi-natural ecosystems in Switzerland. Atmos. Environ. 2019, 211, 214-225. [CrossRef]

49. Vanguelova, E.I.; Pitman, R.M. Nutrient and carbon cycling along nitrogen deposition gradients in broadleaf and conifer forest stands in the east of England. Forest Ecol. Manag. 2019, 447, 180-194. [CrossRef]

50. Schmitz, A.; Sanders, T.G.M.; Bolte, A.; Bussotti, F.; Dirnbock, T.; Johnson, J.; Penuelas, J.; Pollastrini, M.; Prescher, A.K.; Sardans, J.; et al. Responses of forest ecosystems in Europe to decreasing nitrogen deposition. Environ. Pollut. 2019, 244, 980-994. [CrossRef]

51. Song, L.; Kuang, F.H.; Skiba, U.; Zhu, B.; Liu, X.J.; Levy, P.; Dore, A.; Fowler, D. Bulk deposition of organic and inorganic nitrogen in southwest China from 2008 to 2013. Environ. Pollut. 2017, 227, 157-166. [CrossRef] 
52. Schichtel, B.A.; Gebhart, K.A.; Morris, K.H.; Cheatham, J.R.; Vimont, J.; Larson, R.S.; Beachley, G. Long-term trends of wet inorganic nitrogen deposition in Rocky Mountain National Park: Influence of missing data imputation methods and associated uncertainty. Sci. Total Environ. 2019, 687, 817-826. [CrossRef]

53. Thomas, R.Q.; Zaehle, S.; Templer, P.H.; Goodale, C.L. Global patterns of nitrogen limitation: Confronting two global biogeochemical models with observations. Glob. Chang. Biol. 2013, 19, 2986-2998. [CrossRef]

54. Johnson, J.; Cummins, T.; Aherne, J. Critical loads and nitrogen availability under deposition and harvest scenarios for conifer forests in Ireland. Sci. Total Environ. 2016, 541, 319-328. [CrossRef]

55. Izquieta-Rojano, S.; Garcia-Gomez, H.; Aguillaume, L.; Santamaria, J.M.; Tang, Y.S.; Santamaria, C.; Valino, F.; Lasheras, E.; Alonso, R.; Avila, A.; et al. Throughfall and bulk deposition of dissolved organic nitrogen to holm oak forests in the Iberian Peninsula: Flux estimation and identification of potential sources. Environ. Pollut. 2016, 210, 104-112. [CrossRef] [PubMed]

Publisher's Note: MDPI stays neutral with regard to jurisdictional claims in published maps and institutional affiliations.

(C) 2020 by the authors. Licensee MDPI, Basel, Switzerland. This article is an open access article distributed under the terms and conditions of the Creative Commons Attribution (CC BY) license (http://creativecommons.org/licenses/by/4.0/). 